\title{
Türkiye'de STEM Eğitimi Konusunda Yapılan Çalışmalar Üzerine Bir Araştırma: Meta-Sentez Çalışması
}

\author{
Research on STEM Education Studies in Turkey: A Qualitative Meta- \\ Synthesis Study \\ Hamdican YILDIRIM*, Sevinç GELMEZ-BURAKGAZI** \\ • Geliş Tarihi: 10.07.2019 • Kabul Tarihi: 29.12.2019 • Çevrimiçi Yayın Tarihi: 10.03.2020
}

\section{$\ddot{O} \mathbf{z}$}

Türkiye'de STEM eğitimi için yapılan araştırma sayısında son yıllarda bir artış gözlenmektedir. Ancak mevcut bilgimize göre, nitel araştırmalarda ortaya çıkan anlayışların birikimine ve sentezine yönelik yürütülmüş bir çalışma bulunmamaktadır. Mevcut çalışma, meta sentez yöntemini kullanarak, Türkiye'de STEM eğitimi ile ilgili yapılan çalışmaların nitel bulgularından yola çıkarak kapsamlı bir bakış açısı ve anlatı ile sunması yönüyle önem taşımaktadır. Araştırma bulgularının, mevcut durumu ortaya koyarak, gelecekte Türkiye'de STEM eğitimine yönelik yürütülecek çalışmalara yön göstermesi beklenmektedir. Bu amaçla toplam 12 çalışma incelenmiştir. Analiz neticesinde sürece dahil edilen çalışmaların nitel bulguları üç boyutu ortaya çıartmıştır. Bu boyutlar okul içinde veya okul dışında yapılan STEM uygulamalarının sonuçlarına, STEM eğitimine yönelik bilişsel düzeydeki mevcut duruma ve öğretmen adaylarının STEM disiplinleri arasında ilişki kurmalarına odaklandığı belirlenmiştir. Bu boyutlar doğrultusunda tekrar incelenen çalışmaların nitel bulguları üç ortak tema altında sentezlenmiştir: 21. Yüzyıl Becerileri ve STEM Alanlarına Yönelik İlgi, Algı ve Görüşler ile STEM Disiplinleri Arasındaki İlişkilerdir. Araştırma sonucunda, öğretmenlere, öğretmen adaylarına ve araştırmacılara öneriler sunulmuştur.

Anahtar sözcükler: STEM, STEM eğitimi, Türkiye'de STEM eğitimi, nitel meta-sentez yöntemi.

Atıf:

Yıldırım, H., ve Gelmez-Burakgazi, S. (2020). Türkiye'de STEM eğitimi konusunda yapılan çalışmalar üzerine bir araştırma: Meta-sentez çalışması. Pamukkale Üniversitesi Eğitim Fakültesi Dergisi,50, 291-314. doi: 10.9779/pauefd.590319

\footnotetext{
* Hacettepe Üniversitesi, Eğitim Bilimleri Enstitüsü, Eğitim Programları ve Öğretim Anabilim Dalı, Yüksek Lisans Öğrencisi, hamdican.yildirim@ hacettepe.edu.tr, ORCID ID: 0000-0003-4078-5335

** Dr. Öğr. Üyesi, Hacettepe Üniversitesi, Eğitim Programları ve Öğretim Anabilim Dalı, sevincgb@ hacettepe.edu.tr, ORCID ID: 0000-0002-4553-1433
} 


\begin{abstract}
In recent years an increase in the number of researches for STEM education in Turkey is observed. However, to the best of our knowledge, there is no study on the accumulation and synthesis of the insights emerging in qualitative research. The present study, using the meta-synthesis method, the studies related to STEM education in Turkey based on the qualitative findings to provide a comprehensive perspective and narrative aspect is important. Research findings -by revealing the current situation in Turkey- are expected to show the future direction of the work to be carried out for STEM education. For this purpose, a total of 12 studies were examined. Three dimensions appeared in consequence of these analyses. These dimensions are determined to focus on: Firstly, the results of STEM practices in or out of school; Secondly, current situation at the cognitive level for STEM education, and thirdly; pre-service teachers' ability of interdisciplinary relationships of STEM. In line with these dimensions, the qualitative findings of the studies reviewed were synthesized under three common themes: 21st Century Skills and the STEM Interest, Perception and Opinions Towards STEM Fields, and the Relations between STEM Fields. As a result of the research, suggestions were given to teachers, teacher candidates and the researchers.
\end{abstract}

Keywords: STEM, STEM Education, STEM Education in Turkey, qualitative meta-synthesis method

\title{
Cited:
}

Yıldırım, H., \& Gelmez-Burakgazi, S. (2020). Research on STEM education studies in Turkey: A qualitative meta-synthesis study. Pamukkale Üniversitesi Ĕ̈itim Fakültesi Dergisi, 50, 291-314. doi: 10.9779/pauefd.590319 


\section{Giriş}

Bilimsel ve teknolojik gelişmelerin hızla ilerlemesi günümüz dünyasını şekillendirmekte, bireylerin ve toplumların çağa ayak uydurması için sahip olması gereken özellikler bu gelişmelere paralel olarak değişim göstermektedir. 21. yüzyılda bilimsel ve teknolojik gelişmelerin gösterdiği bu hızlı gelişim pek çok imkânla beraber yeni sorunları ve problemleri de beraberinde getirmektedir. Bireylerin sadece temel okuryazarlık yeteneklerine sahip olmas1 günümüz problemleri karşısında onları yetersiz bırakmakta ve çağın gelişmelerine ayak uydurmalarını zorlaştırmaktadır. Bireylerin 21. yüzyılın bu hızlı yenilenmesine ayak uydurması ve bu çağda başarılı olması için sahip olması gereken bazı beceriler Partnership for 21st Century Learning [P21] (2015) tarafından yaratıcılık ve yenilikçilik, iletişim ve iş birliği, eleştirel düşünme ve problem çözme, bilgi, iletişim ve teknoloji okuryazarllğ 1 olarak belirlenmiştir. Bu becerilerin disiplinler arası doğal bir etkileşimin ve küresel konuların doğrultusunda kazandırılması amaçlanmaktadır.

Günümüz dünyasında küresel ölçekteki rekabette var olmak isteyen ülkelerin, ekonomik problemlerin üstesinden gelebilmeleri için yenilikçi bir anlayışla büyüme politikalarını benimsemesi ve bu doğrultuda katma değer sağlayacak iş firsatları yaratmaları gerekmektedir (OECD, 2010). Bu bağlamda, geleceğin iş gücü olacak bireylerin eğitimi önem kazanmıştır. Küresel ölçekteki ekonomik rekabette var olabilmek için gereken nitelikli iş gücünün bilim, teknoloji, mühendislik ve matematik alanlarına yetkin bireyler yetiştirilmesi hedeflenmekte ve eğitimin bu bireylerin yetiştirilmesi hususunda önemli bir rolü olduğu düşünülmektedir (Akgündüz, 2016; Bybee, 2010; OECD, 2017).

$\mathrm{Bu}$ ihtiyaçların giderilmesi amacıyla ilk olarak Amerika Birleşik Devletleri'nde ortaya çıkan STEM (Fen, Teknoloji, Mühendislik ve Matematik) eğitimi, öğrenci ve öğretmenlerin ilgi ve hayat deneyimleri doğrultusunda bir STEM disiplinini, bir diğer STEM disiplini ile bütünleştirerek öğretmeyi amaçlamakta; problemlere yönelik eleştirel ve ilişkisel bir bakış açısı geliştirmeyi hedeflemektedir (Çorlu, Capraro ve Capraro, 2014; DoE, 2010; Şahin, Ayar ve Adıgüzel, 2014). STEM eğitimi, bireylerin disiplinlere yönelik edindiği bilgi ve becerileri pratik uygulamalarla kullanmalarını ve günlük hayat problemleriyle entegre etmeyi amaçlamaktadır (Wang, Moore, Roehrig ve Park, 2011). Yenilikçi bir anlayışla, öğrencilerin eleştirel düşünme, problem çözme, bilimsel okuryazarlık gibi yeterliklerini geliştirmeyi amaçlayan STEM eğitimi, bireylerin disiplinler arasındaki doğal ilişkileri fark ederek, disiplinlere yönelik bilgi ve becerilerini geliştirmekte ve bireyleri bilgiye dayalı bir ekonomiye hazırlamaktadır (NRC, 2011).

Küresel dünyanın değişen çağ doğrultusundaki yeni becerilerle donatılmış bireylere yönelik ihtiyaçları ülkemizde de kendisini göstermiş, STEM alanlarında yetişmiş, 21. yüzyıl becerilerine sahip bireylere ihtiyaçlara vurgu yapılmıştır (Akgündüz ve diğerleri, 2015; PWC ve TÜSİAD, 2017; TÜSİAD, 2014). Eğitim alanındaki ihtiyaç ise geleceğin nitelikli iş gücünü yetiştirmeye yönelik kaygılara paralel olarak ortaya çıkmıştır. Bununla beraber ülkemizin uluslararası değerlendirme çalışmaları olan PISA, TIMMS, PIAAC gibi sınavlarda diğer ülkelere nazaran düşük puanlar ile alt sıralarda yer alması, ülkemizin kalkınması ve uluslararası rekabette var olması bağlamında eğitim alanında yenilik ihtiyacını doğurmuştur. Gelişmelerin bir sonucu olarak Millî Eğitim Bakanlığı, 2016 yılında STEM eğitiminin entegrasyonuna yönelik bir yol haritası yayınlamıştır (MEB, 2016). 
STEM eğitimine yönelik uluslararası alan yazındaki çalışmaların geçmişi 2000'li yılların başlarına kadar dayanıyor olsa da ulusal alan yazındaki çalışmalar son yıllara yoğunlaşmaya başlamıştır. Bu çalışmada, Türkiye'de STEM eğitimine yönelik yapılan çalışmaların genel çerçevesinin sunularak eğiliminin belirlenmesi ve gelecek çalışmalara yönelik bir fikir sunması amaçlanmıştır. Bu amaç doğrultusunda çalışmada şu soruya yanıt aranmıştır:

- Türkiye'de STEM eğitimine yönelik yapılan çalışmalardan elde edilen bulgulara göre hangi temalara ulaşılabilir?

\section{STEM Eğitiminde Disiplinler Arası Entegrasyon}

STEM eğitimi, disiplinleri arasında bütünlük kuran bir yapıdadır. STEM disiplinleri olarak tanımlanabilen bilimin, teknolojinin, mühendisliğin ve matematiğin doğal yapıları da bu disiplinlerin birbirleri arasındaki etkileşimi zorunlu bir hale getirmektedir. Disiplinler arasındaki bu bütünlük STEM çalışmalarında ve farklı araştırmacıların tanımlarında önemli bir yer tutmaktadır. Bu başlıkta disiplinler arası ilişkilendirmenin önemini vurgulayan çalışmalara yer verilecektir.

STEM eğitiminde disiplinler arası entegrasyona yönelik Sanders (2009) iki veya daha fazla STEM disiplini ile bir veya daha fazla okul dersi arasında öğrenmeyi ve öğretmeyi amaçlayan yaklaşımların yer alması gerektiğini vurgulamıştır. Wang, Moore, Roehring ve Park (2011) ise küreselleşen ve gelişen dünyada karşılaşlacak yeni problemlerin çözümü için tek bir alana yönelik uzmanlığın yeterli olmayacağını, problemlerin çözümünde fen, teknoloji, mühendislik ve matematik disiplinlerinde bulunan kavram ve becerilerin ilişkilendirilmesinin önemli olacağını belirtmiştir. Weber, Fox, Levings ve Bouwma-Gearhart (2013) ise STEM eğitimine yönelik ilginin artmasına rağmen, öğretmenlerin STEM alanları arasındaki doğal ilişkinin yeterli düzeyde anlaşılmadığını belirtmiştir. Moore ve diğerleri (2014) disiplinler arası entegrasyonu, dört STEM disiplininin veya bazılarının, gerçek dünya problemlerinin çözümü için bir araya getirilmesi olarak tanımlamıştır. Moore ve Smith (2014) STEM eğitimindeki disiplinler arası entegrasyonun bağlam ve içerik entegrasyonu olarak iki ayrı şekilde gerçekleşebileceğini belirtmiştir. Bağlamsal entegrasyonda mühendislik süreçleri, öğrenmenin hedefinden ziyade öğrenmeyi motive eden, öğrenme süreçlerine yardımcı olan bir roldedir. İçerik entegrasyonunda ise, mühendislik süreçleri doğrudan öğrenmenin bir parçası olarak karşımıza çıkmaktadır. İçerik entegrasyonu, mühendisliğin bir veya birden fazla alanla etkileşim içerisinde olduğu, bir ders kapsamındaki öğrenme hedeflerinin sonucunda bir mühendislik öğrenmesinin de yer aldığı bir modeldir.

Çorlu, Capraro ve Capraro (2014) ise bireylerin ilgileri ve hayat deneyimleri doğrultusunda bir STEM disiplinini, diğer bir STEM disiplini ile bütünleştirerek öğretim süreçlerinde yer almasına değinmiştir. Bryan, Moore, Johnson ve Roehrig (2015) ise bu entegrasyon sürecini, ilgili teknolojilerin mühendislik ve mühendislik tasarım süreçlerinin entegrasyonuyla, bilimi ve/veya matematiği içeren disiplinlerin öğretilmesi ve öğrenilmesi olarak belirtmiştir.

\section{STEM Eğitiminde Mühendislik ve Mühendislik Tasarım Süreci}

STEM alanlarından biri olan mühendislik, bilimsel bilgiyi ve matematiksel bilgiyi kapsayan, insanlık yararına olabilecek yapıların ve süreçlerin tasarlanmasını, test edilmesini ve 
uygulanmasını içeren bir disiplindir. Mühendislik STEM eğitiminde kendisine "mühendislik tasarım süreci”nin entegrasyonu ile yer bulmaktadır. Kelley ve Knowles'a (2016) göre mühendislik tasarım sürecinin öğretim programlarında yer alması, mühendislik uygulamalarının öğretim programlarına dahil edilmesi adına önemli bir noktadır.

Mühendislik tasarım süreci, mühendislerin işlevsel ürünleri, sistemleri veya süreçleri oluşturmada kullandıkları, değerlendirmeleri ve tanımlamaları içeren bir dizi sistematik adım olarak tanımlanabilir (Dym ve diğerleri, 2005). Accreditation Board for Engineering and Technology'e (ABET) [Mühendislik ve Teknoloji Akreditasyon Kurulu] (2017) göre mühendislik tasarım süreci, "Temel bilimlerin, matematiğin ve mühendisliğin, belirlenen bir hedefe ulaşmak için kaynakları en iyi şekilde kullanmayı amaçlayan -çoğu zaman kendini tekrarlayan- bir karar verme sürecidir" (s. 7). Mühendislik tasarım süreci, STEM disiplinleri arasında bir ilişki kurmakta ve disiplinler arası entegrasyon sürecinde önemli bir rol üstlenmektedir. Mühendislik tasarım süreçlerinin öğretim programlarında yer alması STEM disiplinlerinin kendilerine uygulama alanı bulmasına imkân tanımaktadır. Bu başlıkta mühendislik tasarım sürecinin entegrasyonuna yönelik çalışmalara yer verilecektir.

2003-2013 yılları arasinda ABD'de NSF [National Science Foundation] tarafindan desteklenen proje kapsamında Teksas eyaletinde 150 öğretmene yaz aylarında "Mühendislik Deneyimlerini Zenginleştirme (The Enrichment Experiences in Engineering (E3)" program1 uygulanmıştır. Bu program kapsamında öğretmenlerin mühendislik alanıyla ilgili eğitim alması ve bu tecrübeleri derslerinde uygulamaları planlanmıştır. Araştırmacılar, programın katılımcı öğretmenler üzerindeki uzun vadeli etkisini ve öğretmenlerin mühendislik anlayışlarındaki değişimleri, farkındalıklarını ve algılarını incelemişlerdir. Araştırmanın bulguları E3 programının öğretmenleri mühendislik alanı ile ilgili başarılı bir şekilde eğittiğini göstermektedir (Autenrieth, Lewis ve Butler-Purry, 2017).

Yaşar ve diğerleri (2006) öğretmenlerin mühendislik algılarını ve tasarım, mühendislik ve teknoloji öğretimine yatkınlıklarını değerlendirmek amacıyla bir anket geliştirmiştir. Mühendislik tasarım sürecine ilişkin bir başka çalışma ise Marulcu ve Sungur (2012) tarafından yapılmıştır. Türkiye'de bir devlet üniversitesinde yapılan çalışmanın bulguları, katılımcıların mühendislik yaklaşımının fen bilimleri eğitiminde önemli olduğunu ve öğretmen adaylarının mühendisliğe yönelik temel kavramlara sahip olduğunu göstermektedir. Ancak temel kavram bilgisine sahip olan öğretmen adaylarının mühendislik tasarım sürecine hâkim olmadığ görülmüştür. Mühendislik tasarım sürecini disiplinler arası pratik bir uygulama yaklaşımı olarak gören ve öğrencilerin STEM alanlarına yönelik ilgilerini uyandıracağını düşünen Wheeler ve diğerleri (2014) sınıf içi bir uygulama yapmıştır. Bu uygulama kapsamında öğrencilerin bir hücrenin enerji üretimini gözlemlemeleri amacıyla bir motor ve fan yardımı ile elektrokimyasal hücre tasarlamaları ve enerji üretimini gözlemlemeyi amaçlanmıştır. Bu etkinlik kapsamında öğrencilerin, mühendislerin ve bilim insanlarının gerçek dünya sorunlarını nasıl çözdüğünü anlamak için gerekli olan bilimsel ve mühendislik uygulamalarına katılmaları hedeflenmiş̧ir. Ercan ve Şahin (2015) yürüttükleri çalışma kapsamında 7 hafta boyunca 7. Sınıf öğrencilerinin fen bilimleri dersi kapsamındaki "kuvvet ve hareket" konusunu STEM uygulamalarıyla işlemiş ve uygulama sonunda öğrencilerin akademik başarıları ile mühendislik bilgilerinin arttığ gözlenmiştir. Akaygün ve Aslan-Tutak (2016) Türkiye'deki bir devlet üniversitesinde hizmet öncesi düzeyde 38 matematik ve kimya öğretmen adayı ile gerçekleştirdiği çalışmada, işbirlikçi 
STEM modülü (CLT-STEM) ile öğretmen adaylarının STEM ve mühendislik algılarındaki düzey belirlenmiştir. Bu fenomenolojik çalışma sonucunda adayların STEM ve mühendislik algılarında bir gelişme gözlenmiştir. Aydın-Günbatar ve diğerleri (2018) tarafından gerçekleştirilen çalışmada ise STEM uygulamalarının hizmet öncesi düzeydeki kimya öğretmenlerinin, içerik bilgisi, STEM anlayışları ve mühendislik tasarımı görüşleri üzerindeki etkisinin incelenmesi amaçlanmıştır. Bu kapsamda 12 hafta süren eğitim kapsamında, 8 öğretmen adayıyla karma desende yürütülen çalışmada adaylardan her uygulama sonucunda görüşler toplanmış, adaylara kurs öncesi ve sonrası kimya başarı testi uygulanmış ve adaylardan kurs öncesi ve sonrasında yarı-yapılandırılmış görüşme formlarıyla görüşler toplanmıştır. Çalışma sonucunda, tasarım tabanlı STEM eğitiminin öğretmen adaylarının içerik bilgilerini derinleştirmelerine yardımcı olduğunu ortaya konulmuştur. Bununla beraber katılımcıların STEM'in disiplinler arası yapısından bahsedebildiği, mühendislik ve mühendislik tasarım sürecine yönelik bilgilerini derinleştirdikleri gözlenmiştir.

\section{STEM Eğitimine Yönelik Görüşler}

STEM eğitimin kendine özgü yapısı, sadece bir disiplinde uzmanlaşmak için eğitim gören öğretmenlerin aşina olmadığı bir durumdur. Bu bağlamda STEM kapsamındaki alanlara ve bu alanların okul derslerinde nasıl bir uygulama imkânı bulacağına yönelik görüşler ve fikirler araştırmacıların ilgilendiği bir başka konu olmuştur.

Kızılay (2016) çalışmasında 25 fen bilgisi öğretmen adayının STEM alanları ve STEM eğitimi ile ilgili görüşlerini belirlemiştir. 10 adet açık uçlu soru vasıtasıyla toplanan veriler içerik analizi ve betimsel analiz ile incelenmiş, elde edilen bulgular adayların STEM alanları arasında ilişki kurabildiğini göstermiştir. STEM eğitimi anlayışının güçlendirilmesi için, hizmet öncesi öğretmen adaylarının STEM alanlarını ne derecede ve nasıl kavramlaştırdıklarını belirlemeyi amaçlayan Radloff ve Guzey (2016) Amerika Birleşik Devletleri'nde bir üniversitedeki öğretmen adaylarına yazılı ve görsel bölümleri içeren bir anket uygulamıştır. Bulgular neticesinde hizmet öncesi düzeydeki öğretmen adaylarının STEM eğitimi ile ilgili ortak kavramlar oluşturmanın yanı sıra, yaratıcılıktan uzak, öğretmen merkezli gibi STEM eğitimi ile çelişen ifadeleri de kullandıkları görülmüştür. STEM eğitiminin anlaşılması ve kavramsallaştırılmasına yönelik yapılan bu çalışmada, hizmet öncesi öğretmen adaylarının STEM eğitimine daha kolay ulaşabilmesi amacıyla çeşitli yolların sunulması gerekliliği belirtilmiştir.

Özçakır-Sümen ve Çalışıcı (2016) "çevre eğitimi” dersi kapsamında STEM uygulamalarına yer vermiş ve hizmet öncesi öğretmen adaylarının zihin haritaları ve görüşleri incelenmiştir. 42 sınıf öğretmeni adayı ile yürütülen çalışmada katılımcıların STEM eğitimi konusunda zengin bir kavramsal yapıya sahip olduklarını ve STEM alanlarını hem kendi içinde hem de çevre eğitimi ile ilişkilendirdikleri gözlenmiştir. Ayrıca katılımcılar STEM eğitimini verimli bulduklarını belirtmişlerdir. Çınar, Pırasa ve Paliç-Sadoğlu (2016) STEM eğitimiyle ilgili bir atölye çalışmasına katılan öğretmen adaylarının görüşlerini incelemek amacıyla açık uçlu sorulardan oluşan bir anket uygulamıştır. Atölye çalışmaları sonucunda katılımcıların STEM'e yönelik pozitif bir görüşe sahip oldukları belirlenmiştir. Katılımcılar ayrıca STEM'i uygulanması eğlenceli, öğrencilerin psikomotor ve zihinsel becerilerini geliştiren, işbirlikli öğrenmeyi teşvik eden bir yaklaşım olarak tanımlamışlardır. Bunun yanı sıra katılımcılar STEM'in sadece bilim odaklı olduğunu düşünmüş, disiplinler arası yaklaşımı belirtmemişlerdir. 
Smyrnova-Trybulska, Morze, Kommers, Zuziak ve Gladun (2016) tarafından yürütülen çalışmada Polonya ve Ukrayna'dan toplam 91 fen bilgisi öğretmeni ve fen bilgisi öğretmeni adayına 15 soruluk "robotik ve çocuklar" adlı pedagojik bir araştırma ile ilgili anket uygulanmıştır. Polonya ve Ukrayna'da hizmet içi öğretmenler ve öğretmen adayları arasında yapılan anketin sonuçları, katılımcıların yarısından fazlasının STEM eğitiminin fen bilimleri eğitiminde önemli bir rolde bulunduğunu belirtmiştir. Bununla beraber ilköğretim düzeyindeki atölye çalışmaları ve diğer faaliyetlerle STEM eğitimini tanıtmanın gerekliliğini anladığını göstermektedir.

\section{Yöntem}

Bu çalışmada, nitel araştırma bulgularını sentezlemeyi amaçlayan, nitel araştırma desenlerinden "meta-sentez" yöntemi kullanılmıştır. Meta-sentez, aynı konu üzerine yapılan nitel araştırmaların bulgularının sentezlenip yeniden yorumlanmasını amaçlayan, üst düzey soyutlama ve genelleştirebilir boyuta ulaştıran, çalışmaları araştırmacılar için daha erişilebilir hale getiren çalışmalardır (Çalık ve Sözbilir, 2014; Noblit ve Hare, 1988; Zimmer, 2006). Metasentez, alandaki nitel araştırma bulgularının metodolojik olarak yorumlanmasına dayanan bir araştırma desenidir. Nicel araştırma bulgularını içeren, pozitivist bir yaklaşımda olan metaanaliz çalışmaları ile bu yönüyle ayrılır (Brown ve Lan, 2015). Meta-sentez yöntemiyle, Türkiye'de STEM eğitimine yönelik yapılan çalışmaların incelenmesi, gelecek çalışmalara, araştırmacılara ve paydaşlara Türkiye'de STEM eğitiminin mevcut durumunun resmedilmesi amaçlanmıştır.

\section{Veri Toplama Süreci}

Araştırmaların sistematik olarak incelenmesi Ekim 2018 - Mart 2019 arasında yapılmış, bu amaçla ERIC (Educational Resources Information Center), Web of Science, Scopus, Google Scholar, TÜBİTAK-ULAKBİM ve YÖK Ulusal Tez Sistemi veri tabanlarında "STEM", "STEM Eğitimi”, “STEM Education", "STEM Teaching", "Integrated STEM Education", "FeTeMM", "FeTeMM Eğitimi" anahtar kelimeleri kullanılmıştır.

Çalışmanın amacına hizmet etmesi amacıyla, çalışmaların yürütüldüğü konumları filtreleme imkânı tanıyan ERIC, Web of Science, Scopus gibi veri tabanlarında konum filtresi Türkiye olarak belirlenmiştir. Zaman aralığı olarak Türkiye'de STEM eğitimi ile ilgili çalışmaların yoğunlaşmaya başladığı 2014-2019 yılları belirlenmiştir. Stem (kök) kavramını barındıran biyoloji ve tıp alanlarındaki çalışmaların elenmesi için veri tabanlarında listelenen çalışmalardan uygulama alanları "eğitim ve eğitim araştırmaları (education \& educational research)" olan çalışmalar seçilmiştir. Örneğin, Web of Science'da arama kısmına bu filtrelemeleri içeren: "ts=(stem* AND education) NOT SU=Life Sciences \& Biomedicine AND $\mathrm{CU}=$ Turkey" komutu yazılmıştır.

Eklenen filtrelere rağmen arama sonuçlarında listelenen, farklı ülkelerde yürütülmüş araştırmaların ayıklanması neticesinde 58 çalışmaya ulaşılmıştır. Tarama sonucunda elde edilen çalışmalar yazarlar tarafından incelenmiş, başlıklar, özetler ve araştırma desenleri göz önüne alınarak listelenmiştir. Bu çalışmanın amacına hizmet etmesi için listelenen çalışmaların Türkiye'de yürütülmüş olması, son beş yıl içerisinde yayınlanmış olması ve STEM eğitimine yönelik uygulamaları içermesi gözetilmiştir. Bu perspektifin dışında kalan veya nitel araştırma deseninde olmayan çalışmalar inceleme kapsamının dışında tutulmuştur. Bu bağlamda, meta- 
sentez çalışmalarının doğasına uygun olarak sadece nitel çalışmalar araştırma kapsamına dahil edilmiştir. Bunun sonucunda, Türkiye'de STEM eğitimiyle ilgili son beş yılda nitel desenlerde yürütülen 12 çalışmaya ulaş1lmıştır.

Bilimsel araştırmalar için önem arz eden örneklem büyüklüğü argümanı nitel araştırmalar için de önemli bir husustur. Büyük örneklemler nitel çalışmalar için temaların oluşturulmasını engelleyebilecek bir faktör olarak göze çarpmaktadır (Bondas ve Hall, 2007). Bu noktada meta-sentez çalışmaları için 10-12 çalışma sayısı yeterli görülmektedir (Bondas ve Hall, 2007; Sandelowski, Docherty ve Emden, 1997; Paterson, Thorne, Canam ve Jillings, 2001). Bu bağlamda bu araştırmaya dahil edilen çalışma sayısı, meta-sentez çalışmaları için önerilen sayıya uygundur.

Araştırmaya dahil edilen çalışmaların alt bölümlerine yönelik bir özet Tablo 1'de sunulmaktadir.

Tablo 1: Meta-sentez çalışmasına dahil edilen çalışmalar

\begin{tabular}{|c|c|c|c|c|}
\hline Künye & Örneklem & Çalışmanın Amacı & Veri Toplama Araçları & $\begin{array}{l}\text { Verilerin } \\
\text { Analizi }\end{array}$ \\
\hline $\begin{array}{l}\text { Ayar, M. } \\
\text { (2015) }\end{array}$ & $\begin{array}{l}27 \text { Lise } \\
\text { Öğrencisi }\end{array}$ & $\begin{array}{l}\text { Doğrudan mühendislik } \\
\text { deneyimlerinin } \\
\text { ögrencilerin ögrenme } \\
\text { süreçleri, uygulamalı ve } \\
\text { zihinsel etkinliklerde nasıl } \\
\text { rol aldıkları, mühendislik } \\
\text { ve kariyer ilgilieri üzerinde } \\
\text { nasıl bir etkisi olduğunu } \\
\text { belirlemek. }\end{array}$ & $\begin{array}{c}\text { Görüşme, Gözlem, Alan } \\
\text { Notları }\end{array}$ & $\begin{array}{l}\text { İçerik } \\
\text { Analizi }\end{array}$ \\
\hline $\begin{array}{c}\text { Karahan, E., } \\
\text { Canbazoğlu- } \\
\text { Bilici, S. ve } \\
\text { Ünal, A. } \\
\text { (2015) }\end{array}$ & $\begin{array}{l}21 \text { Ortaokul } \\
\text { Öğrencisi }\end{array}$ & $\begin{array}{l}\text { Medya tasarım süreçlerinin } \\
\text { STEM eğitimine } \\
\text { entegrasyonu ile hazırlanan } \\
\text { okul dişı etkinliklerinin, } \\
\text { öğrencilerin fen bilimleri } \\
\text { dersine, fen spotu } \\
\text { etkinliklerine yönelik } \\
\text { tutumlarına ve medya } \\
\text { tasarım süreçlerini } \\
\text { kullanarak fen spotu } \\
\text { hazırlamaya yönelik } \\
\text { düşüncelerini belirlemek. }\end{array}$ & $\begin{array}{c}\text { Fen ve Teknoloji Dersi } \\
\text { Tutum Ölçeği, } \\
\text { Öğrencilerin Hazırladığı } \\
\text { Medya Ürünleri, Fen } \\
\text { Spotu Hazırlama } \\
\text { Formları, Yarı- } \\
\text { Yapılandırılmış } \\
\text { Görüşmeler, } \\
\text { Araştırmacı Notları }\end{array}$ & $\begin{array}{l}\text { Wilcoxon } \\
\text { İşaretli } \\
\text { Sıralar Testi, } \\
\text { İçerik } \\
\text { Analizi, } \\
\text { Açık } \\
\text { Kodlama, } \\
\text { Aksiyal } \\
\text { Kodlama }\end{array}$ \\
\hline $\begin{array}{l}\text { Baran, E., } \\
\text { Canbazoğlu- } \\
\text { Bilici, S., } \\
\text { Mesutoğlu, C. } \\
\text { ve Ocak, C. } \\
\quad(2016)\end{array}$ & $\begin{array}{l}40 \text { Ortaokul } \\
\text { Öğrencisi }\end{array}$ & $\begin{array}{l}\text { Devlet okullarında okuyan } \\
\text { daha önce STEM ile ilgili } \\
\text { bir programa katılmamış } \\
\text { ancak STEM alanlarına ilgi } \\
\text { duyan öğrencilerin okul } \\
\text { dışı bir program } \\
\text { sonrasındaki algılarını } \\
\text { belirlemek. }\end{array}$ & $\begin{array}{c}\text { Açık Uçlu Sorular } \\
\text { (Etkinlik Değerlendirme } \\
\text { Formları) }\end{array}$ & $\begin{array}{l}\text { İçerik } \\
\text { Analizi }\end{array}$ \\
\hline $\begin{array}{l}\text { Bozkurt- } \\
\text { Altan, E. ve } \\
\text { Ercan, S. } \\
(\mathbf{2 0 1 6})\end{array}$ & $\begin{array}{l}24 \text { Öğretmen } \\
\text { (Fen } \\
\text { Bilimleri) }\end{array}$ & $\begin{array}{l}\text { Mesleki gelişim } \\
\text { programının, } \\
\text { öğretmenlerinin STEM } \\
\text { eğitimine yönelik algı ve } \\
\text { yeterliklerine olan etkiyi } \\
\text { araştırmak. }\end{array}$ & $\begin{array}{c}\text { Teachers' Perceptions } \\
\text { on STEM Education } \\
\text { Questionnaire (TPSEQ), } \\
\text { Öğretmenlerin } \\
\text { Geliştirdiği STEM Ders } \\
\text { Planları }\end{array}$ & $\begin{array}{l}\text { Karşılaştırm } \\
\text { alı İçerik } \\
\text { Analizi }\end{array}$ \\
\hline Çınar, S., & 57 Öğretmen & STEM eğitimine ilişkin & Açık Uçlu Sorular & Betimsel \\
\hline
\end{tabular}




\begin{tabular}{|c|c|c|c|c|}
\hline $\begin{array}{l}\text { Pirasa, N. ve } \\
\text { Sadoğlu, G. } \\
\text { (2016) }\end{array}$ & $\begin{array}{c}\text { Adayı } \\
\text { (37 Fen } \\
\text { Bilimleri, 20 } \\
\text { Matematik) }\end{array}$ & $\begin{array}{l}\text { atölye çalışmaları yapan } \\
\text { bir programa katılan } \\
\text { öğgetmen adaylarının } \\
\text { görüşlerini incelemek. }\end{array}$ & (STEM Anketi) & Analiz \\
\hline $\begin{array}{l}\text { Eroğlu, S. ve } \\
\text { Bektaş, O. } \\
\text { (2016) }\end{array}$ & $\begin{array}{l}5 \text { Öğretmen } \\
\text { (Fen } \\
\text { Bilimleri) }\end{array}$ & $\begin{array}{c}\text { Fen Bilimleri } \\
\text { öğretmenlerinin STEM ve } \\
\text { STEM temelli ders } \\
\text { etkinliklerine yönelik } \\
\text { görüşlerini ortaya } \\
\text { çikartmak. }\end{array}$ & $\begin{array}{l}\text { Yarı-Yapılandırılmış } \\
\text { Görüşmeler }\end{array}$ & $\begin{array}{l}\text { İçerik } \\
\text { Analizi }\end{array}$ \\
\hline $\begin{array}{l}\text { Hacioğlu, Y., } \\
\text { Yamak, H. } \\
\text { ve Kavak, N. } \\
\quad(2016)\end{array}$ & $\begin{array}{l}192 \\
\text { Öğgretmen } \\
\text { Adayı (Fen } \\
\text { Bilimleri) }\end{array}$ & $\begin{array}{c}\text { Fen bilimleri } \\
\text { öğretmenlerinin STEM ve } \\
\text { fen eğitimi ile ilgili bilişsel } \\
\text { yapılarının ortaya } \\
\text { konulması. }\end{array}$ & $\begin{array}{c}\text { Kelime İlişkilendirme } \\
\text { Testi (Word Association } \\
\text { Test - WAT) ve } 8 \\
\text { hizmet öğretmen adayı } \\
\text { ile yarı-yapılandırılmış } \\
\text { görüşmeler. }\end{array}$ & $\begin{array}{l}\text { Betimsel } \\
\text { Analiz }\end{array}$ \\
\hline $\begin{array}{l}\text { Özçakır- } \\
\text { Sümen, Ö. ve } \\
\text { Çalışıcı, H. } \\
\text { (2016) }\end{array}$ & $\begin{array}{c}42 \text { Öğretmen } \\
\text { Adayı (Sınıf } \\
\text { Öğretmenliği } \\
\text { ) }\end{array}$ & $\begin{array}{l}\text { Sınıf Öğretmenliği lisans } \\
\text { programı ikinci yılı } \\
\text { kapsamında “Çevre } \\
\text { Eğitimi” dersini STEM } \\
\text { yaklaşımıyla işleyip çeşitli } \\
\text { uygulamalardan sonra } \\
\text { zihin haritaları ve } \\
\text { katılımcıların görüşlerini } \\
\text { incelemek. }\end{array}$ & $\begin{array}{l}\text { Zihin Haritaları, Yarı- } \\
\text { Yapılandırılmış } \\
\text { Görüşmeler }\end{array}$ & $\begin{array}{l}\text { İçerik } \\
\text { Analizi }\end{array}$ \\
\hline $\begin{array}{l}\text { Gökbayrak, } \\
\text { S. ve Karışan, } \\
\text { D. } \\
(2017)\end{array}$ & $\begin{array}{l}20 \text { Ortaokul } \\
\text { Öğrencisi }\end{array}$ & $\begin{array}{c}\text { STEM uygulamaları } \\
\text { hakkında ortaokul } \\
\text { öğrencilerinin görüşlerini } \\
\text { incelemek. }\end{array}$ & Görüşme & $\begin{array}{l}\text { Betimsel } \\
\text { Analiz }\end{array}$ \\
\hline $\begin{array}{l}\text { Çetin, A. ve } \\
\text { Balta, N. } \\
\text { (2017) }\end{array}$ & $\begin{array}{l}42 \text { Öğretmen } \\
\text { Aday1 (Fen } \\
\text { Bilimleri) }\end{array}$ & $\begin{array}{l}\text { Hizmet öncesi düzeydeki } \\
\text { fen bilimleri } \\
\text { öğretmenlerinin STEM } \\
\text { etkinlikleri ve bu } \\
\text { etkinliklerde } \\
\text { kullanabilecekleri } \\
\text { materyaller hakkındaki } \\
\text { görüsleri incelemek. }\end{array}$ & $\begin{array}{l}\text { Yapılandırılmış } \\
\text { Görüşmeler }\end{array}$ & $\begin{array}{l}\text { İçerik } \\
\text { Analizi }\end{array}$ \\
\hline $\begin{array}{l}\text { Erdoğan, İ ve } \\
\text { Çiftçi, A. } \\
\text { (2017) }\end{array}$ & $\begin{array}{l}7 \text { Öğretmen } \\
\text { Aday1 (Fen } \\
\text { Bilimleri) }\end{array}$ & $\begin{array}{l}\text { Hizmet öncesi düzeydeki } \\
\text { fen bilimleri } \\
\text { öğretmenlerinin STEM } \\
\text { uygulamalarına ilişkin } \\
\text { görüşlerini incelemek. }\end{array}$ & $\begin{array}{l}\text { Yarı-Yapılandırılmış } \\
\text { Görüşmeler }\end{array}$ & $\begin{array}{l}\text { İçerik } \\
\text { Analizi }\end{array}$ \\
\hline $\begin{array}{l}\text { Delen, İ. ve } \\
\text { Uzun, S. } \\
\text { (2018) }\end{array}$ & $\begin{array}{l}50 \text { Öğretmen } \\
\text { Aday1 } \\
\text { (Matematik) }\end{array}$ & $\begin{array}{l}\text { Matematik Öğretmenliği } \\
\text { bölümünün son sınıfındaki } \\
\text { hizmet öncesi öğretmen } \\
\text { adaylarının STEM } \\
\text { uygulamalarını analiz } \\
\text { etmek. }\end{array}$ & $\begin{array}{l}\text { Ders Planları, Yar1- } \\
\text { Yapılandırılmış } \\
\text { Görüşmeler }\end{array}$ & $\begin{array}{l}\text { Betimsel } \\
\text { Analiz }\end{array}$ \\
\hline
\end{tabular}

\section{Verilerin Analizi}

Meta-sentez çalışmalarında verilerin analizi için altı önemli başlık ortaya çıkmaktadır (Noblit ve Hare, 1988).

Aşama 1 - Sentezi Belirlemek Amacıyla Karar ve Başlangıç

Aşama 2 - Çalışmanın Hedefine Uygun Çalışmalara Ulaşmak 
Aşama 3 - Çalışmaların Okunması ve Değerlendirilmesi

Aşama 4 - Farklı Çalışmalar Arasındaki İlişkilerin Belirlenmesi

Aşama 5 - Çalışmaların Birbirlerine Aktarılması ve Nitel Meta-Sentezin Oluşturulması

Aşama 6 - Sentezin İfade Edilmesi

Verilerin analizi esnasında Noblit ve Hare'in (1988) yukarıda verilen 6 aşaması takip edilirken, Sandelowski, Docherty ve Emden (1997) tarafindan tartışıldığ gibi "çalışmaların bütünlüğünü koruyacak şekilde yeterince ayrıntılı bir şekilde analiz etme ve kullanılabilir bir sentez üretilmediği kadar ayrıntıya dalmama" (s.370) hususlarına dikkat edilmiştir.

$\mathrm{Bu}$ çalışmada araştırma kapsamı Türkiye'de STEM eğitimine yönelik yürütülen çalışmalar olarak belirlenmiş ve bu kapsama bağlı olarak araştırma sorusu tasarlanmıştır. Ardından, alanyazın taraması için dahil etme ve hariç tutma kriterleri belirlenmiştir. Anahtar kelimelerin belirlenmesinin ardından öncelikle biyoloji ve tıp alanındaki çalışmalar elenmiş ve sadece eğitim bilimleri alanında Türkiye'de yürütülen STEM çalışmalarına ulaşılmıştır. Bu çalışmalar incelendikten sonra nicel ve karma desenli çalışmalar kapsam dışında bırakılmış ve nitel çalışmaların incelenmesine başlanmıştır. Hedefe uygun çalışmalara ulaşıldıktan sonra bu çalışmalar tekrar gözden geçirilmiş ve değerlendirilmiştir. Meta-sentez kapsamında yer alan 12 çalışma yazarlar tarafından tekrar okunup özetlenmiştir (Tablo 1). Çalışmaların benzer ve farklı yönleri belirlenmiş ve temalar oluşturulmaya başlanmıştır. Çalışma kapsamında dahil edilmesi kararlaştırılan çalışmalar tekrar okunmuş, çalışmalardaki fikirler ve bulgulardaki kilit noktalar sonucunda üç boyuta (STEM uygulamalarıyla ilgi ve becerilerin artması, STEM'e yönelik mevcut bilişsel düzey, STEM disiplinleri arasında ilişki kurabilme) ulaşılmıştır. Çalışmalardan ortaya çıkan üç boyutun sınıflandırılması için bu boyutlara paralel olarak temalar (21. Yüzyıl Becerileri ve STEM Alanlarına Yönelik İlgi, Alg1 ve Görüşler ve STEM Disiplinleri Arasındaki İlişkiler) belirlenmiştir. Belirtilen bu temalar doğrultusunda çalışmaların nitel bulgularından yararlanılarak sonuçlar birleştirilmiştir ve yorumlanmıştır. Temalar çerçevesinde elde edilen bulgular, yararlanılan çalışmalardan alıntılarla sunulmuştur.

Jensen ve Allen (1994) tarafından da belirtildiği gibi meta-sentez çalışmasının geçerliği ve güvenirliğine ilişkin bir kısım önlemler alınmıştır. Bu kapsamda araştırmanın geçerliğine kanıt olarak, çalışma süreci kapsamlı ve ayrıntılı olarak ele alınmış, çalışmaya dahil etmedışında tutma ölçütleri belirtilmiş; bulgular çalışmaya dahil edilen araştırmaların katılımcılarından aynen alıntılar yolu ile desteklenmiş ve gerekli yerlerde takibi kolaylaştırmak açısından tablolar ile sunum yoluna gidilmiştir. Bunların yanı sıra, Miles ve Huberman (1994) tarafından açıklandığı gibi, bulguların mevcut alanyazın ve kavramsal çerçeve ile ilişkisi de dikkate alınmıştır. Araştırma süreci, araştırmacılar ve Eğitim Programları ve Öğretim bilim dalında doktora eğitimini tamamlamış bir dış uzman arasındaki teyit ve görüş birliği ile yürütülmüştür.

\section{Bulgular}

Araştırmaya dâhil edilen çalışmaların başlıkları ve özetleri gözden geçirilmiş, daha sonra tam metinlerine erişim sağlanmıştır. Çalışmalar incelendiğinde, STEM eğitimine yönelik bazı boyutlar ortaya çıkmıştır. Birinci boyut, ortaokul ve lise öğrencilerinin okul içinde veya okul dışında yapılan STEM uygulamalarıyla, 21. yüzyıl becerileri çerçevesinde STEM alanlarına yönelik ilginin ve becerilerin arttırılmasına odaklanılmaktadır (Ayar, 2015; Baran, Canbazoğlu- 
Bilici, Mesutoğlu ve Ocak, 2016; Gökbayrak ve Karışan, 2017). İkinci boyut, STEM'e yönelik bilişsel düzeydeki mevcut durumun tartışıldığı çalışmaların incelenmesi esnasında ortaya çıkmıştır. Bu boyut öğrencilerin, öğretmen adaylarının ve öğretmenlerin STEM eğitimine yönelik sahip oldukları algılarını, farkındalık düzeylerini ve mesleki gelişim programları, STEM uygulamaları gibi çalışmalar sonrasında STEM eğitimine yönelik görüşlerini belirlemeye odaklanmıştır (Bozkurt-Altan ve Ercan, 2016; Çetin ve Balta, 2017; Çınar, Pırasa ve PaliçSadoğlu, 2016; Eroğlu ve Bektaş, 2016; Hacığlu, Yamak ve Kavak, 2016; Karahan, Canbazoğlu-Bilici ve Ünal, 2015; Özçakır-Sümen ve Çalışıcı, 2016). Üçüncü boyut ise öğretmen adaylarının STEM disiplinleri arasında ilişki kurmalarına yönelik mevcut durumun ortaya konulmasına odaklanmıştır (Çınar, Pırasa ve Paliç-Sadoğlu, 2016; Delen ve Uzun, 2018).

Bu boyutlar göz önüne alınarak çalışmalar tekrar gözden geçirilmiş ve üç tema altında düzenlenmiştir. Bunlar; 21. Yüzyıl Becerileri ve STEM Alanlarına Yönelik İlgi, Alg1 ve Görüşler ile STEM Disiplinleri Arasındaki İlişkilerdir. İncelenen temalarda, geçerlik kanıtlarının sağlanması amacıyla orijinal çalışmalardan alıntılara yer verilmiştir.

\section{Yüzyıl Becerileri ve STEM Alanlarına Yönelik İlgi}

STEM eğitiminin en önemli hedeflerinden birisi, STEM alanları olan fen, teknoloji, mühendislik ve matematik alanlarında yetişmiş, bu alanlarda kariyer yapmayı hedefleyen bireyler yetiştirmektir. Bu bağlamda, 21. yüzyıl becerileri çerçevesinde STEM uygulamaları ile öğrencilere STEM'e yönelik ilgi ve beceri kazandırılması hedeflenmektedir. Bu tema, 21. yüzyıl becerileri çerçevesinde STEM alanlarına yönelik ilginin ve kazandırılan becerilerin bulgularda nasıl yer aldığı ile ilgilenmektedir. STEM uygulamaların öğrencilerin STEM alanlarına yönelik kariyer ilgilerini, STEM alanlarına yönelik becerilerini arttırdığı ve mühendislik faaliyetlerine yönelik yetkinliklerini arttırdığı gözlenmiştir (Ayar, 2015; Baran, Canbazoğlu-Bilici, Mesutoğlu ve Ocak, 2016). Bu çalışmalara ilişkin bir özet Tablo 2'de sunulmuştur.

\section{Tablo 2: STEM Uygulamalarının İncelendiği Çalışmalar}

\begin{tabular}{|c|c|c|c|c|c|c|c|c|}
\hline \multicolumn{2}{|c|}{ Çalıșmanın } & \multicolumn{2}{|c|}{ Uygulamanın } & \multicolumn{5}{|c|}{ Uygulama Kapsamı } \\
\hline Yazarı & Örneklemi & Yeri & Süresi & $\begin{array}{c}\text { Teknoloji } \\
\text { Kullanımı }\end{array}$ & $\begin{array}{l}\text { STEM } \\
\text { İlgisine } \\
\text { Etki }\end{array}$ & $\begin{array}{c}\text { Algı ve } \\
\text { Tutuma } \\
\text { Etki }\end{array}$ & $\begin{array}{l}\text { Mühendislik } \\
\text { Süreçlerinin } \\
\text { Entegrasyonu }\end{array}$ & $\begin{array}{c}\text { Akıl } \\
\text { Yürütme } \\
\text { ve } \\
\text { Problem } \\
\text { Çözme }\end{array}$ \\
\hline $\begin{array}{l}\text { Ayar } \\
(2015)\end{array}$ & $\begin{array}{l}27 \text { Lise } \\
\text { Öğrencisi }\end{array}$ & $\begin{array}{c}\text { Okul Diş1: } \\
\text { Robotik Yaz } \\
\text { Kamp1 }\end{array}$ & $\begin{array}{c}12 \\
\text { Gün }\end{array}$ & $\checkmark$ & $\checkmark$ & $\checkmark$ & $\checkmark$ & $\checkmark$ \\
\hline $\begin{array}{c}\text { Baran ve } \\
\text { diğerleri } \\
(2016)\end{array}$ & $\begin{array}{l}40 \text { Ortaokul } \\
\text { Öğrencisi }\end{array}$ & $\begin{array}{l}\text { Okul Dışı: } \\
\text { Haftasonu } \\
\text { Uygulanan } \\
\text { STEM } \\
\text { Eğitim } \\
\text { Programı } \\
\text { Etkinlikleri }\end{array}$ & 5 Gün & $\checkmark$ & $\checkmark$ & $\checkmark$ & $\checkmark$ & $\checkmark$ \\
\hline
\end{tabular}

Ayar (2015) yürüttüğü çalışmada yaz kamplarının geleneksel fen eğitiminden hedef, pratik çalışma ve sosyal yapı açısından ayrıldığını ve öğrencilere mühendislik faaliyetleri ile ilgili beceriler kazandırdığını belirtmiştir.

Sınıfın amacı üniversite giriş sınavında başarılı olmakla sınırlıyken, kamptaki hedefler bir robot tasarlama konusunda deneyim kazanmak ve öğrencilerin yarışma 
için hazırladıkları robotlar sayesinde mühendislik ile tanışmalarıydı. Öğrenciler, sınıflarda teorik içerik bilgisi ve daha az uygulamalı etkinliklerle ilgilenirken, robotik yaz kampı, problemlerini çözmeleri teorik içerik bilgisi ile öğrencilerin ihtiyaç duyduğu uygulamalı ve zihinsel etkinlikleri daha fazla sunmuştur. Örgün sınıflardaki sosyal yapı, öğretmenlerin bilgi yetkisine ve sınavlara yönelik bireyselleştirilmiş öğrenmeye dayanırken, robotik yaz kampında sosyal yapının ana unsurları, iş birliği, paylaşım ve dayanışma olmuştur. Böylelikle, robotik yaz kampı, öğrencileri mühendislik faaliyetleri ile ilgili olarak daha özerk, yetkin ve ilişkili hale getirme potansiyeline sahiptir (s.1666).

STEM eğitimi, öğrencilerin disiplinler arası ilişkiler kurarak 21. yüzyıl becerileri çerçevesinde problemlere inovatif çözümler üretmesini amaçlar. $\mathrm{Bu}$ nedenle 21. yüzyıl becerilerinin STEM uygulamalarıyla kazandırılabilmesi en önemli konular arasında yer almaktadır. Baran ve diğerleri (2016), yürüttüğü çalışmanın sonucunda öğrencilerin tartışma, işbirlikli çalışma, eleştirel düşünme, akıl yürütme, probleme ilişkin bir çözüm tasarlama gibi 21. yüzyıl becerileri arasında yer alan yeteneklerin STEM uygulamalarıyla kazandırılabildiği gözlenmiştir. Bununla beraber tartışma, mühendislik ve tasarım becerileri ve araştırma yapma becerilerinin de geliştiği görülmüsstür:

(...) öğrencilerden biri şöyle açılıyordu: "STEM uygulamalarının, tartışma, sorgulama ve muhakeme etme becerilerini geliştirdiğime inanıyorum". Öğrenciler ayrıca dengeli ve dirençli köprüler inşa etme ve hızlı araba tasarlama gibi etkinlikler ile mühendislik becerilerini geliştirdiklerini belirtti. $\mathrm{Bu}$ becerileri tasarım, bilgisayar, matematik ve fen bilgisi becerileri takip etti. Öğrencilerden biri şunları ifade etti: "Hayal gücümü ve mühendislik becerilerimi bu etkinlikler ile geliştirdim" (s.16).

$\mathrm{Bu}$ çalışmalara paralel olarak, Çınar, Pırasa ve Paliç-Sadoğlu'nun (2016) yaptığı çalışmada hizmet öncesi öğretmen adayları, STEM uygulamalarının derslerdeki başarıyı arttırdığını, öğrenmeyi daha sosyal bir hale getirdiğini, yaratıcı düşünmeyi teşvik ettiğini, zihinsel gelişime ve kariyer tercihine katkıda bulunduğunu şöyle belirtmiştir:

Kısa bir süre içinde bir şeylerin ezberlendiği ve daha sonra unutulduğu bir eğitim sistemimiz var. Bunu aşmak için yaparak öğrenmeliyiz. Bu uygulama ile öğrencilerimize küçük bir mühendis veya bir bilim insanının düşünme yapısını öğretiyoruz. Böylelikle soyut düşünme yetenekleri gelişiyor. Ayrıca problem çözme, akıl yürütme, ilişkilendirme becerileri de gelişir. Eğer matematiği ögretmek istiyorsak bu uygulamaya ihtiyacımız var. Mühendisler, bilim insanları ve iyi bir eğitim sistemi istiyorsak bu uygulamaya ihtiyacımız var (s. 1484).

\section{Algı ve Görüsşler}

$\mathrm{Bu}$ tema, STEM eğitimine yönelik algıları ve görüşleri, uygulamaların öğretmen (Bozkurt-Altan ve Ercan, 2016; Eroğlu ve Bektaş, 2016) ve öğretmen adayları (Çetin ve Balta, 2017; Çınar, Pırasa ve Paliç-Sadoğlu, 2016; Erdoğan ve Çiftçi, 2017; Hacıoğlu, Yamak ve Kavak, 2016; Özçakır-Sümen ve Çalışıcı, 2016) üzerindeki etkilerine odaklanmaktadır.

Teorik olarak sadece bir STEM disiplininde uzmanlaşan öğretmenlerin, uygulamalarla yeni deneyimler kazanması, bu deneyimler sonucunda algılarının belirlenmesi, yeni pedagojik yaklaşımların keşfedilmesi ve diğer STEM uygulamalarına ilham vermesi için bir fırsat olarak görülmektedir (Çetin ve Balta, 2017; Çınar, Pırasa ve Paliç-Sadoğlu, 2016; Erdoğan ve Çiftçi, 2017; Eroğlu ve Bektaş, 2016; Özçakır-Sümen ve Çalışıc1, 2016). Bu mesele bazı çalışmaların deseni gereği açıkça vurgulanırken (Çınar, Pırasa ve Paliç-Sadoğlu, 2016; Özçakır-Sümen ve 
Çalışıc1, 2016, bazı çalışmalarda örtülü olarak ifade edilmiştir (Çetin ve Balta, 2017; Eroğlu ve Bektaş, 2016).

Öğretmen adayları STEM eğitimini, her yaş için uygulanabilecek, sosyal etkileşimi ve işbirlikli öğrenmeyi teşvik edecek, etkili ve sürekli öğrenmeyi sağlayacak bir eğitim olarak tanımlamış, STEM etkinliklerini ve bu etkinlikler kapsamında hazırlanan, kullanılan materyallerin öğrenmeyi kolaylaştırdığını, akademik başarıyı arttırdığını, öğrencilerin çevrelerindeki insanlarla etkileşime geçerek sosyalleştiğini ve psikomotor becerilerini geliştirdiğini belirtmişlerdir (Çetin ve Balta, 2017; Çınar, Pırasa ve Paliç-Sadoğlu, 2016). Nitekim Karahan, Canbazoğlu-Bilici ve Ünal (2015) 8. sınıf öğrencileriyle yürüttüğü çalışma sonucunda, öğrencilerin fen bilimleri eğitimine yönelik olumlu bir tutum geliştirdiğini, öğrencilerin STEM uygulamalarıyla fen bilimleri dersinden keyif aldığını belirlemiştir.

STEM eğitiminin, öğrencilerin gelişimine katkıda bulunacağını belirten öğretmen adayları, yeterli materyalin ve firsatın sağlanması durumunda bu uygulamalardan çekinmeyeceklerini belirtmişlerdir (Çınar, Pırasa ve Paliç-Sadoğlu, 2016). STEM uygulamalarına yönelik fırsatların ve materyallerin sağlanmasına ilişkin bir benzer bulgu Eroğlu ve Bektaş (2016) tarafından fen bilgisi öğretmenleri ile yürütülen çalışmada da ortaya çıkmıştır. Bu çalışmaya katılan öğretmenler, materyal ve imkân konusunda çekinceleri olduğunu, ancak STEM uygulamalarına karşı olumsuz bir tutum sergilemediklerini belirtmiştir (Eroğlu ve Bektaş, 2016).

Öğretmen adaylarının yeni pedagojik yaklaşımları kazanması, öğrencilerin ihtiyaçlarına yönelik etkin çözümler üretebilecek duruma gelmesi STEM uygulamalarıyla mümkün olabilmektedir. Özçakır-Sümen ve Çalışıcı (2016) yürüttüğü çalışmada sınıf öğretmenliği bölümünde öğrenim gören öğretmen adaylarının, STEM uygulamaları aracıllı̆ı ile fen ve matematiğe karşı olumsuz tutum besleyen öğrencilerin görüşlerini olumlu olarak etkileyebileceklerini düşündükleri sonucunu elde etmişlerdir. Çalışmaya katılan bir öğretmen adayı durumu şöyle belirtmiştir:

Öğrencilerin fen ve matematiğe karşı soğuk olmasının nedeni, bu disiplinlerin pratik kullanımları olmadığını düşünmeleri ve nerede kullanıldığııı bilmemeleridir. Eğer matematiğin pratik kullanımları olduğunu, gelecekte işe yarayabileceğini fark ederlerse, daha fazla ilgi gösterip daha çok çalışacaklar (s.471).

Erdoğan ve Çiftçi (2017) fen bilgisi öğretmen adayları ile yürüttüğü çalışmada 8 haftalık bir eğitim vermiştir. Eğitime katılan öğretmen adaylarının çoğunluğunun STEM eğitimini uygulama konusunda istekli oldukları yine öğretmen adaylarının çoğunluğunun STEM eğitimi ile ilgili daha fazla bilgi almak istediği görünmüştür. Bütün katılımcıların STEM eğitiminin temel mantığını farklı argümanlarla ifade ettiği tespit edilmiştir. Araştırmacıların bu soru çerçevesinde edindiği 21. yüzyıl becerilerinin kazanılması, günlük hayat problemlerinin çözülmesi, disiplinler arasında ilişki kurulması, tasarım becerilerinin geliştirilmesi gibi cevaplar, STEM eğitimi ile ilgili eğitimden geçen hizmet öncesi düzeydeki öğretmenlerin bu eğitimi içselleştirebildiğini gösterebilmektedir.

STEM uygulamalarından faydalanmak için mevcut eğitim sistemine entegrasyonu ile ilgili algılara yönelik bulgulara ulaşan Bozkurt-Altan ve Ercan (2016) hizmet içi öğretmen eğitimlerine, öğretmenler arası işbirliğine, öğretmenlerin kişisel gelişime açık bir halde olmasına önem verilmesi gerektiğine ilişkin sonuçlar elde etmişlerdir. Öğretmenlere uygulanan 
mesleki gelişim programı sonucunda öğretmenlerin çoğu öğretim sürecinin iyileştirilmesi ile ilgili önerilerde bulunmuş ve tasarım tabanlı fen eğitiminin benimsenebileceğini, teknoloji, mühendislik ve matematiğin fen derslerine entegrasyonunu sağlayabileceğini belirtmiştir

\section{STEM Disiplinleri Arasındaki İlişskiler}

STEM eğitimi, fen, teknoloji, mühendislik ve matematiğin doğal ilişkisinin günlük hayat durumları üzerinden uygulama alanı bulmasını ve öğrencilerin bu alanlardaki teorik bilgilerini kullanmasını amaçlamaktadır. Öğretmenler, STEM alanlarından birinde uzmanlaşacak şekilde yetişmektedirler ancak disiplinler arası ilişkiyi kurmaları başarılı bir STEM eğitimi için gereklidir. Öğretmenlerin bu ilişkiyi kurması amacıyla atölye çalışmalarında aktif olarak rol aldığı görülmektedir. Nitekim Çınar, Pırasa ve Paliç-Sadoğlu (2016) tarafından yürütülen atölye çalışmasında katılımcı öğretmen adayları aktif olarak STEM faaliyetlerinde yer almıştır. Bununla beraber Bozkurt-Altan ve Ercan (2016) çalışmalarında 9 günlük bir mesleki gelişim programı düzenlemiş ve bu programda teorik bilginin yanı sıra pratik uygulamalara da yer vererek adayların ve eğitmenlerin süreç içerisinde aktif olmasını sağlamışlardır. AydınGünbatar ve diğerleri (2018) araştırmalarında düzenledikleri STEM kursunda katılımcılara entegre STEM yaklaşımını ve mühendislik tasarım yaklaşımına yönelik bir eğitim verdikten sonra farklı haftalarda 5 adet STEM uygulamasını katılımcılarla yapmışlardır. Bu uygulamaların yapılmasından önce araştırmacılar, katılımcılara uygulamalarla paralel olacak günlük hayat problemleri sunulmuş ardından katılımcılar ikişerli gruplar halinde bu problemlere yönelik çözümler üretmeye başlamışlardır. Grupla çalışma etkinliklerinin veriminin arttırılması amacıyla her etkinlikte grupların üyeleri değiştirilmiştir. Öğretmenlerin genellikle aktif olarak yer aldığı bu çalışmaların disiplinler arası ilişki kurmalarına yardımcı olduğu ve STEM farkındalıklarını arttırdığı gözlenmiştir (Çınar, Pırasa ve Paliç-Sadoğlu, 2016; Bozkurt-Altan ve Ercan, 2016; Gökbayrak ve Karışan, 2017; Aydın-Günbatar, vd., 2018)

$\mathrm{Bu}$ temada, STEM eğitiminin disiplinler arası ilişki kuran boyutuna odaklanan çalışmalar ele alınacaktır (Delen ve Uzun, 2018; Hacıoğlu, Yamak ve Kavak, 2016; ÖzçakırSümen ve Çalışıc1, 2016).

Hacıŏ̆lu ve diğerleri (2016) yaptığı çalışmada öğretmen adaylarının STEM eğitimine yönelik bilişsel yapılarını belirlemeyi amaçlamıştır. Bulgular ışığında öğretmen adaylarının fen ve teknoloji arasında bir bağ kurabildiği ancak bu bağı mühendislik ve matematik ile genişletemediği görülmüş̧ür. Çınar ve diğerleri (2016) çalışmasında öğretmen adaylarının STEM eğitimini sadece fen bilimi merkezli bir yaklaşım olarak gördüklerini belirtmişlerdir. Nitekim bu durum STEM eğitiminin doğasına aykırı bir durumdur. STEM eğitimi bir disipline odaklanılmasından ziyade disiplinler arasındaki ilişkiye odaklanılmasını öngörmektedir.

Öğrenciler, okul derslerinde STEM alanları ile ilişkili konuları farklı derslerde ve genellikle birbirleriyle ilişkilendirilmeden görmektedir. STEM alanları arasındaki doğal ilişkiler, uygulamalar vasıtasıyla öğrenciler tarafindan keşfedilebilmektedir. Gökbayrak ve Karışan (2017) yürüttüğü çalışmada öğrencilerin \%75'inin STEM disiplinleri arasında ilişki kurabildiğini belirtmiştir. Öğrenciler bu uygulamalarla STEM alanlarının ilişkilerini kavrarken, bu alanlardaki derslerine ilişkin olumlu tutum geliştirmektedirler (Gökbayrak ve Karışan, 2017).

Delen ve Uzun (2018) yürüttüğü çalışmada öğretmen adaylarına bir süre STEM eğitimini tanıtmıştır. Bu eğitim sırasında eğitmenler aktif, katılımcılar ise pasif bir rol 
üstlenmiştir. Katılımcılar programın ikinci aşamasında uygulayacakları ders programlarını hazırlamış ve son aşamada bu hazırlanan programları kendi gruplarında uygulamışlardır. Uygulamalar neticesinde öğretmen adaylarının matematik ve fen bilimleri arasında bir ilişki kurabildiği, ancak teknoloji entegrasyonu ve tasarıma yansıtma konusunda sıkıntı yaşadıkları görülmüştür. Bu da adayların STEM disiplinlerini birbirine entegre etmede yaşadıkları sıkıntıyı göz önüne sermektedir.

Ancak, Özçakır-Sümen ve Çalışıcı (2016) tarafından yürütülen çalışmada ise öğretmen adaylarının bir eğitim programından sonra bu dört disiplin arasında bir ilişki kurabildiği görülmüştür. Katılımcılar etkinliklerden sonra dört disiplinin birbirine doğal ilişkilerle bağl1, birbirleri arasında uygulama alanı bulabilen disiplinler olduğunu keşfettiklerini belirttiler.

[Bu derste] bunların [STEM alanlarının] birbirine nasıl bağlı olduğunu anladım. Matematik olmadan, mühendislikten söz edilemez. Bilim ilerledikçe, teknoloji ilerliyor ve teknoloji ilerledikçe insanlar daha üretken oluyorlar. Bu alanlar birbirlerine kesinlikle bağl1 (s.470).

Öğretmenlerin ve öğretmen adaylarının disiplinler arası ilişkiyi derslerine yansıtmaları için, disiplinler arası ilişki kurmalarını sağlayacak çalışmalara, algılarını geliştirecek, farklı disiplinlere ait bilgilere ve bu bilgileri kendi dersleriyle ilişkilendirebilecekleri uygulamalara daha fazla yer verilmeli, öğretmen ve öğretmen adaylarının bu uygulamaları geliştirmeleri teşvik edilmelidir.

\section{Tartışma ve Sonuç}

Bu çalışmada, STEM eğitimi ile ilgili Türkiye'de yürütülen çalışmalarla ilgili alanyazın gözden geçirilmiştir. Türkiye'de yürütülen çalışmalar sistematik olarak gözden geçirilmiş ve üç boyutun Türkiye'de yürütülen çalışmalara yön verdiği gözlenmiştir. STEM uygulamalarıyla kazanılan beceriler ve STEM alanlarına yönelik ilgi üzerindeki etki, STEM eğitimine yönelik bilişsel farkındalık ve STEM disiplinleri arasında ilişki kurma boyutları açısından çalışmalar tartışılmıştır.

Bu meta-sentez çalışmasında Türkiye'de yürütülen STEM çalışmalarına ilişkin üç boyut ve bu boyutlardan üç ortak tema ortaya çıkartılmıştır. Geleceğin iş gücü olacak, farklı düzeydeki öğrencilerin STEM uygulamalarıyla mevcut becerilerinin geliştirilebileceği ve kariyer ilgilerini STEM alanlarına yönlendirebileceği vurgulanmıştır. Ayrıca STEM alanları ile ilişkili derslerine yönelik olumsuz tutuma sahip olan öğrencilerin yine bu uygulamalarla derslerine karşı tutumlarının olumlu olarak değiştiği belirtilen bir başka konu olmuştur. Derslerin uygulayıcısı konumundaki öğretmenlerin ve öğretmen adaylarının genel olarak STEM eğitimine yönelik olumlu görüşler belirttiği ancak materyal ve zaman konusunda sıkıntılar yaşanabileceğini vurguladıkları belirlenmiştir. Aynı zamanda öğretmenlerin ve öğretmen adaylarının STEM eğitiminin disiplinler arası yapısını kavradığı, mühendislik tasarım süreçlerine derslerinde yer vermek istediği gözlenmiştir. Mevcut öğretmen yetiştirme programları öğretmenleri sadece bir STEM disiplininde uzmanlaştırmakta ve lisans eğitimi süresince mühendislik süreçlerine yer vermemektedir.

STEM eğitimi ile ilgili ulusal ve uluslararası alanyazın incelendiğinde fen, teknoloji, mühendislik ve matematik arasında ilişki kurulmasını amaçlayan çalışmalar ile (Breiner, vd., 2012; Bryan, vd., 2015; Çınar, Pırasa, ve Paliç-Sadoğlu, 2016; Çorlu, Capraro, ve Capraro, 
2014; Delen ve Uzun, 2018; Hacığlu, Yamak, ve Kavak, 2016; Moore, vd., 2014; ÖzçakırSümen ve Çalışıc1, 2016; Sanders, 2009; Wang, vd., 2011; Weber, vd., 2013; Yamak, Bulut ve Dündar, 2014) mühendislik ve mühendislik tasarım sürecinin eğitim süreçlerine entegrasyonunu amaçlayan çalışmalar (Akaygün ve Aslan-Tutak, 2016; Autenrieth, vd., 2017; Ayar, 2015; Aydın-Günbatar, vd., 2018; Ercan ve Şahin, 2015; Marulcu ve Sungur, 2012, Wheeler, vd., 2014; Yaşar, vd., 2006) ortaya çıkmaktadır.

STEM disiplinleri arasındaki etkileşimden okul dişı ve okul içi uygulamalar aracılığı ile yararlanılması, öğrencilerin okul derslerine yönelik tutumlarını olumlu olarak etkilediği, akademik başarı, tutum, bilimsel süreç becerileri, problem çözme becerilerini geliştirdiği gözlenmiştir (Ayar, 2015; Baran, Canbazoğlu-Bilici, Mesutoğlu ve Ocak, 2016; Gökbayrak ve Karışan, 2017). Ancak uygulamalar genel olarak fen bilimleri dersine odaklanmış, STEM alanlarını ilgilendiren matematik, bilişim teknolojileri gibi dersler bu uygulamalar için kullanılmamıştır. Öğretmen adaylarıyla yapılan uygulamalar da genellikle fen bilimleri öğretmen adaylarıyla sınırlı kalmıştır. Uygulamalar sonucunda öğretmen adaylarının teknolojiyi, süreçlere entegre etmekte sıkıntı çektikleri gözlenmiştir (Delen ve Uzun, 2018).

Disiplinler arasındaki etkileşimle paralel olarak mühendislik tasarım süreçlerinin derslere entegrasyonu, okul içi STEM uygulamaları kapsamında çeşitli materyaller kullanılarak yaptırılan, köprüler, basit makineler ve çeşitli robotik çalışmalarla gerçekleşmiştir (Baran, Canbazoğlu-Bilici, Mesutoğlu ve Ocak, 2016; Gökbayrak ve Karışan, 2017). Bu çalışmalar, öğrencilerin günlük hayatta da karşılaşabilecekleri bir probleme daha sistematik yaklaşmalarını sağlamış, işbirlikli çalışmalarını da desteklemiştir. Mühendislik tasarım süreçlerinin okul derslerinde kendine yer bulması, öğrencilerin yenilikçi çözümler üretme, eleştirel düşünme, bilimsel araştırma yürütme gibi 21. yüzyıla hitap eden becerileri kazanmalarına yardımcı olduğu gözlenmiştir.

Bell (2015) İngiltere'de öğretmenlerle yürüttüğü fenomenografik çalışmada, bir öğretmenin STEM'e ilişkin sahip olduğu bilgi ve anlayışı eksik olduğunda, öğrenci öğrenmesi potansiyelinin sınırlı olduğu sonucuna ulaşmıştır. Bu bağlamda Türkiye'de öğretmenlerin, öğretmen adaylarının ve öğrencilerin STEM eğitimine yönelik olumlu görüşlere sahip olması bu eğitim yaklaşımına yönelik bir talebin göstergesi olarak görülebilir. Bununla beraber uygulamalar neticesinde öğretmenlerin STEM'e yönelik bilgi birikimlerinin gelişmesi de STEM'e yönelik eğitimlerin işgörebileceğine ve öğrenci öğrenmelerini geliştirebileceğine bir işaret olarak görülebilmektedir (Acar, vd., 2018; Aydın-Günbatar, vd., 2018; Bozkurt-Altan ve Ercan, 2016; Çınar, Pırasa ve Paliç-Sadoğlu, 2016; Çetin ve Balta, 2017; Çınar, vd., 2016; Eroğlu ve Bektaş, 2016; Gökbayrak ve Karışan, 2017; Hacıoğlu, Yamak ve Kavak, 2016; Sarı, Alıcı ve Şen, 2018; Uğraş ve Genç, 2018; Yamak, Bulut ve Dündar, 2014). STEM uygulamalarının özellikle ortaokul ve lise seviyesinde genellikle robot tasarlamak veya robot kodlamak üzerine olduğu görülmüştür. Robotik uygulamaların, algoritma kurulmasını sağlayarak mühendislik tasarım ve problem çözme süreçlerine, kodlamalarda dikkat edilmesi gereken hususların göz önüne alınarak matematik ve teknoloji bilgisinin kullanımına katk1 sağladığı görülmüştür.

STEM eğitiminin uygulama düzeyinde özellikle fen bilimleri dersine entegrasyonunun mümkün olduğu söylenebilir (Baran, Canbazoğlu-Bilici, Mesutoğlu ve Ocak, 2016; Gökbayrak ve Karışan, 2017). Nitekim mevcut ilkokul ve ortaokul fen bilimleri dersi öğretim programında 
mühendislik ve tasarım becerileri başlığında öğrencilere yenilikçi düşünme yeteneklerinin kazandırmak hedeflenmiş, öğrencilerin fen bilimlerini matematik, mühendislik ve teknoloji ile bütünleştiren bir bakış açısıyla yorumlaması amaçlanmıştır (MEB, 2018). Ancak Türkiye'de ilköğretim düzeyindeki çalışmalarla ilgili bir yetersizlik görünmektedir. Uluslararası alanyazında ilköğretim öğretmenlerinin STEM eğitimine ilişkin yeterlilikleri konusuna odaklanan Rinke, Gladstone-Brown, Kinlaw ve Cappiello (2016) bu doğrultuda deneysel bir çalışma yürütmüş ve bu çalışmanın neticesinde hizmet içi eğitim programına katılan öğretmen adaylarının ders içeriklerinde disiplinler arasındaki ilişkileri güçlendirebilecek uygulamaları yapabildiği, bu doğrultuda ders programları hazırlayabildiklerini tespit etmiştir. $\mathrm{Bu}$ açıdan incelendiğinde ülkemizde de deneysel uygulamaların artması önerilebilir.

STEM eğitimi Türkiye'de son yıllarda sıkça konuşulan popüler bir konu olmasına rağmen, uluslararası bir eğilimin uzun süredir olduğu görülmektedir. Bu noktada Türkiye'de yürütülen çalışmaların artması gerekliliği önerilmektedir. Özellikle küçük ölçekli uygulamalarla STEM eğitimine yönelik incelemelerden ziyade STEM eğitimini derinleştirmeyi, bağlamsal olarak irdelemeyi ve eğitim süreçlerinin bütün paydaşlarının katılacağı bütünsel çalışmalara ihtiyaç duyulmaktadır. Yürütülen çalışmaların genellikle fen bilimleri dersine odaklandığ görülmüş olup, STEM alanları ile ilişkili matematik, bilişim teknolojileri gibi alanlarda da çalışmaların yürütülmesi gelecek çalışmalarda bu alanların da yer alması önerilmektedir. Böylelikle diğer derslerde ortaya çıkabilecek yeni yaklaşımlara, sonuçlara ulaşılması bu alanlardaki öğretim programları ile ilgili yeni tartışmalara ve çalışmalara yardımcı olması düşünülmektedir. Nitekim son yıllarda ülkemizde fen bilimleri derslerine ilişkin öğretim programlarında STEM eğitimine yönelik değişikliklerin yapıldığı gözlenmiştir.

Sistematik inceleme esnasında, Türkiye'de STEM eğitimine yönelik uluslararası düzeyde karşılaştırmalı çalışmaların yapılmadığı görülmüştür. Karşılaştırmalı çalışmalar, uluslararası varsayımların farklı kültürlerdeki yansımaları, bulunduğumuz kültürdeki varsayım yorumları ile kıyaslanması, yeni soruların sorulması ve bu doğrultuda yeni kavramların, davranış biçimlerinin gözlenmesi adına güçlü veriler sunabilen çalışmalardır. STEM eğitimi ile ilgili farklı tecrübeler ile Türkiye'deki tecrübelerin karşılaştırılması, bu anlamda ülkemizin STEM tecrübesini ve ilgili alanyazını zenginleştirebilir. Ulusal boyutta öğretmenlerin ve öğretmen adaylarının derslerinde disiplinler arası ilişkiden yararlanmaları, STEM eğitimine ilişkin bilgi derinliğine ulaşabilmeleri için çeşitli uygulamalara, atölye çalışmalarına ve mesleki gelişim programlarına katılmaları önerilmektedir.

Türkiye'de gerek araştırmacıların gerek politika yapıcıların gündeminde yer alan STEM eğitiminin, Türkiye'deki mevcut bilgi birikimine ait bir tasvir sunulmuştur. 21 . yüzyll becerileri çerçevesinde STEM eğitimine yönelik kazandırılacak becerilerin, STEM eğitimine yönelik alg1 ve görüşlerin ve STEM disiplinleri arasındaki doğal ilişkinin önemi ve bu boyutların eğitim sürecindeki farklı paydaşlar üzerinde nasıl tezahür ettiği incelenmiştir. Bu sentez, STEM becerilerinin farklı uygulamalar vesilesiyle kazandırılması, buna bağlı olarak STEM kapsamındaki disiplinler arasında kurulacak ilişkilerin bireylere farklı bir bakış açısı kazandırabileceğini ve bu bakış açısıyla bireylerin STEM alanlarıyla ilgili daha üst düzey bilişsel becerilere ulaşabileceğinin önemine değinmektedir. 


\section{Kaynakça}

ABET. (2017). Criteria for Accrediting Engineering Programs. Erişim: http://www.abet.org/accreditation/accreditation-criteria/criteria-for-accrediting-engineeringprograms-2018-2019/

Acar, D., Tertemiz, N. ve Taşdemir, A. (2018). The Effects of STEM Training on the Academic Achievement of 4th Graders in Science and Mathematics and their Views on STEM Training Teachers. International Electronic Journal of Elementary Education, 10(4), 505-513.

Akaygün, S. ve Aslan-Tutak, F. (2016). STEM Images Revealing STEM Conceptions of Pre-Service Chemistry and Mathematics Teachers. International Journal of Education in Mathematics, Science and Technology, 4(1), 56-71.

Akgündüz, D. (2016). A Research About the Placement of the Top Thousand Students in Stem Fields in Turkey Between 2000 and 2014. EURASIA Journal of Mathematics, Science ve Technology Education, 12(5), 1365-1377.

Akgündüz, D., Aydeniz, M., Çakmakçı, G., Çavaş, B., Çorlu, M. S., Öner, T. ve Özdemir, S. (2015). STEM eğitimi Türkiye raporu: Günün modası mı yoksa gereksinim mi? [A report on STEM Education in Turkey: A provisional agenda or a necessity?]. İstanbul: İstanbul Aydın Üniversitesi.

Autenrieth, R. L., Lewis, C. W. ve Butler-Purry, K. L. (2017). Long-Term Impact of the Enrichment Experiences in Engineering $\left(\mathrm{E}^{3}\right)$ Summer Teacher Program. Journal of STEM Education, 18(1), 25-31.

Ayar, M. C. (2015). First-hand Experience with Engineering Design and Career Interest in Engineering: An Informal STEM Education Case Study. Educational Sciences: Theory and Practice, 15(6), 1655-1675.

Aydın-Günbatar, S., Tarkın-Çelikkıran, A., Kutucu, E. S. ve Ekiz-Kıran, B. (2018). The influence of a design-based elective STEM course on pre-service chemistry teachers' content knowledge, STEM conceptions, and engineering views. Chemistry Education Research and Practice, 19, 954-972.

Baran, E., Canbazoğlu-Bilici, S., Mesutoğlu, C. ve Ocak, C. (2016). Moving STEM Beyond Schools: Students' Perceptions About an Out-of-School STEM Education Program. International Journal of Education in Mathematics, Science and Technology, 4(1), 9-19.

Bell, D. (2015). The reality of STEM education, design and technology teachers' perceptions: a phenomenographic study. International Journal of Technology and Design Education, 26(1), 6179

Bondas, T. \& Hall, E. O. (2007). A decade of metasynthesis research in health sciences: a meta-method study. International Journal of Qualitative Studies on Health and Well-Being, 2(2), 101-113.

Bozkurt-Altan, E. ve Ercan, S. (2016). STEM Education Program for Science Teachers: Perceptions and Competencies. Journal of Turkish Science Education, 13, 103-117.

Breiner, J. M., Johnson, S. S., Harkness, C. C. ve Koehler, C. M. (2012). What is STEM? A discussion about conceptions of STEM in education and partnerships. School Science and Mathematics, 112(1), 3-11.

Brown, C. P. ve Lan, Y. C. (2015). A qualitative metasynthesis comparing U.S. teachers' conceptions of school readiness prior to and after the implementation of NCLB. Teaching and Teacher Education, 45, 1-13.

Bryan, L. A., Moore, T. J., Johnson, C. C. ve Roehrig, G. H. (2015). Integrated STEM education. C. C. Johnson, E. E. Peters-Burton ve T. J. Moore (Editör) STEM roadmap içinde: A framework for integration. London: Taylor \& Francis.

Bybee, R. W. (2010). Advancing STEM Education: A 2020 Vision. Technology and Engineering Teacher, 70(1), 30-35.

Çalık, M., ve Sözbilir, M. (2014). İçerik Analizinin Parametreleri. Eğitim ve Bilim, 39, 33-38. 
Çetin, A. ve Balta, N. (2017). Pre-Service Science Teachers Views on Stem Materials and Stem Competition in Instructional Technologies and Material Development Course. European Journal of Educational Research, 6(3), 279-288.

Çınar, S., Pırasa, N. ve Paliç-Sadoğlu, G. (2016). Views of Science and Mathematics Pre-service Teachers Regarding STEM. Universal Journal of Educational Research, 4(6), 1479-1487.

Çınar, S., Pırasa, N., Uzun, N. ve Erenler, S. (2016). The Effect of Stem Education on Pre-Service Science Teachers' Perception of Interdisciplinary Education. Journal of Turkish Science Education, 118-142.

Çorlu, M. S., Capraro, R. M. ve Capraro, M. M. (2014). Introducing STEM education: Implications for educating our teachers for the age of innovation. Eğitim ve Bilim, 39(171), 74-85.

Delen, İ. ve Uzun, S. (2018). Matematik öğretmen adaylarının FeTeMM temelli tasarladıkları öğrenme ortamlarının değerlendirilmesi. Hacettepe Üniversitesi Eğitim Fakültesi Dergisi, 33(3), 617-630.

DoE. (2010). A Blueprint for Reform: The Reauthorization of the Elementary and Secondary Education Act. Washington, DC: U.S. Department of Education.

Dym, C. L., Agogino, A. M., Eriş, Ö., Frey, D. D. ve Leifer, L. J. (2005). Engineering Design Thinking, Teaching, and Learning. Journal of Engineering Education, 94(1), 103-120.

Ercan, S. ve Şahin, F. (2015). The Usage of Engineering Practices in Science Education: Effects of Design Based Science Learning on Students' Academic Achievement. Necatibey Eğitim Fakültesi Elektronik Fen ve Matematik Eğitimi Dergisi, 9(1), 128-164.

Erdoğan, İ. ve Çiftçi, A. (2017). Investigating the Views of Pre-service Science Teachers on STEM Education Practices. International Journal of Environmental and Science Education, 1055-1065.

Eroğlu, S. ve Bektaş, O. (2016). STEM Eğitimi Almış Fen Bilimleri Öğretmenlerinin STEM Temelli Ders Etkinlikleri Hakkındaki Görüşleri. Eğitimde Nitel Araştırmalar Dergisi, 4(3), 43-67.

Gökbayrak, S. ve Karışan, D. (2017). Altıncı Sınıf Öğrencilerinin FeTeMM Temelli Etkinlikler Hakkındaki Görüşlerinin İncelenmesi. Alan Eğitimi Araştırmaları Dergisi, 3(1), 25-40.

Hacığlu, Y., Yamak, H. ve Kavak, N. (2016). Pre-Service Science Teachers' Cognitive Structures Regarding Science, Technology, Engineering, Mathematics (STEM) and Science Education. Journal of Turkish Science Education, 13, 88-102.

Jensen, L. A., \& Allen, M. N. (1994). A Synthesis of Qualitative Research on Wellness-Illness. Qualitative Health Research, 4(4), 349-369.

Karahan, E., Canbazoğlu-Bilici, S. ve Ünal, A. (2015). Integration of media design processes in science, technology, engineering, and mathematics (STEM) education. Eurasian Journal of Educational Research, 60, 221-240.

Kelley, T. R. ve Knowles, J. G. (2016). A conceptual framework for integrated STEM Education. International Journal of STEM Education, 3(11), 1-11.

Kızılay, E. (2016). Fen Bilgisi Öğretmen Adaylarının FeTeMM Alanları ve Eğitim Hakkındaki Görüşleri. Journal of Academic Social Science Studies, 47, 403-417.

Marulcu, İ. ve Sungur, K. (2012). Fen Bilgisi Öğretmen Adaylarının Mühendis ve Mühendislik Algılarının ve Yöntem Olarak Mühendislik-Dizayna Bakış Açılarının İncelenmesi. Afyon Kocatepe Üniversitesi Fen Bilimleri Dergisi, 12, 13-23.

MEB. (2016). STEM Ĕgitimi Raporu. Ankara: Millî Ĕgitim Bakanlığı - Yenilik ve Eğitim Teknolojileri

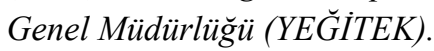

MEB. (2018). Fen Bilimleri Dersi Öğretim Programı -illkokul ve Ortaokul 3, 4, 5, 6, 7 ve 8. Sinuflar. Ankara: Millı̂ Ĕgitim Bakanlı̆̆.

Miles, M. B. ve Huberman, A. M. (1994). Qualitative Data Analysis: A Methods Sourcebook. SAGE Publishing.

Moore, T. J. ve Smith, K. A. (2014). Advancing the State of the Art of STEM Integration. Journal of STEM Education, 15(1), 5-10. 
Moore, T. J., Stohlmann, M. S., Wang, H. H., Tank, K. M., Glancy, A. W. ve Roehrig, G. H. (2014). Implementation and integration of engineering in K-12 STEM education. J. Strobel, M. E. Cardella ve Ş. Purzer (Editör) içinde, Engineering in Pre-College Settings (s. 35-60). Purdue University Press.

Noblit, G. W. ve Hare, R. D. (1988). Meta-Ethnography: Synthesizing Qualitative Studies. SAGE Publications.

NRC. (2011). Successful K-12 STEM education: Identifying effective approaches in science, technology, engineering, and mathematics. Washington, DC: National Academy Press.

OECD. (2010). Measuring Innovation: A New Perspective - online version. Organisation for Economic Co-operation and Development:

http://www.oecd.org/site/innovationstrategy/measuringinnovationanewperspectiveonlineversion.htm adresinden alındı

OECD. (2017). Education at a Glance 2017: OECD Indicators. Paris: OECD Publishing.

Özçakır-Sümen, Ö. ve Çalışıcı, H. (2016). Pre-service Teachers' Mind Maps and Opinions on STEM Education Implemented in an Environmental Literacy Course. Educational Sciences: Theory ve Practice, 16(2), 459-476.

Paterson, B. L., Thorne, S. E., Canam, C. ve Jillings, C. (2001). Meta-study of Qualitative Health Research. A Practical Guide to Meta-analysis and Meta-Synthesis. Thousand Oaks, CA: Sage Publications.

P21. (2015). Partnership for 21st Century Learning, Framework for 21 st Century Learning. http://www.p21.org/about-us/p21-framework adresinden alındı

PWC ve TÜSİAD. (2017). 2023'e Doğru Türkiye'de STEM Gereksinimi. https://www.pwc.com.tr/tr/assets/image/pwc-tusiad-2023-e-dogru-turkiye-de-stem-gereksinimiraporu.pdf adresinden alındı

Radloff, J. ve Güzey, S. (2016). Investigating Preservice STEM Teacher Conceptions of STEM Education. Journal of Science Education and Technology, 25(5), 759-774.

Rinke, C. R., Gladstone-Brown, W., Kinlaw, C. R. ve Cappiello, J. (2016). Characterizing STEM Teacher Education: Affordances and Constraints of Explicit STEM Preparation for Elementary Teachers. School Science and Mathematics, 116(6), 300-309

Smyrnova-Trybulska, E., Morze, N., Kommers, P., Zuziak, W. ve Gladun, M. (2016). Educational Robots In Primary School Teachers' and Students' Opinion About Stem Education For Young Learners. International Conferences on Internet Technologies \& Society (ITS), Education Technologies (ICEduTECH), and Sustainability, Technology and Education (STE), 197-204, Melbourne, Avustralya.

Şahin, A., Ayar, M. C. ve Adıgüzel, T. (2014). Fen, teknoloji, mühendislik ve matematik içerikli okulsonrası etkinlikler ve öğrenciler üzerindeki etkileri. Kuram ve Uygulamada Eğitim Bilimleri, 14(1), 297-322.

Sanders, M. (2009). STEM, STEM Education, STEMmania. The Technology Teacher, 68(4), 20-26.

Sandelowski, M., Docherty, S. ve Emden, C. (1997). Qualitative metasynthesis: Issues and techniques. Research in Nursing and Health, 365-371.

Sarı, U., Alıc1, M. ve Şen, Ö. F. (2018). The Effect of STEM Instruction on Attitude, Career Perception and Career Interest in a Problem-based Learning Environment and Student Opinions. Electronic Journal of Science Education, 22(1) 1-21.

TÜSİAD. (2014). STEM Alanında Eğitim Almış İsgücüne Yönelik Talep ve Beklentiler Araştırması. http://tusiad.org/tr/yayinlar/raporlar/item/download/7014_d28ffa2adda423c6d3852cc01c965993 adresinden alınd 1

Uğraş, M. ve Genç, Z. (2018). Investigating Preschool Teacher Candidates' STEM Teaching Intention and the views about STEM Education. Bartın Üniversitesi Eğitim Fakültesi Dergisi, 7(2) 724-744. 
Wang, H. H., Moore, T. J., Roehrig, G. H. ve Park, M. S. (2011). STEM Integration: Teacher Perceptions and Practice. Journal of Pre-Collage Engineering Education Research, 1(2), 1-13.

Weber, E., Fox, S., Levings, S. B. ve Bouwma-Gearhart, J. (2013). Teachers' Conceptualizations of Integrated STEM. Academic Exchange Quarterly, 17(3), 1-9.

Wheeler, L. B., Whitworth, B. A. ve Gonczi, A. L. (2014). Engineering Design Challenge: Building a voltaic cell in the high school chemistry clasroom. Science Teacher, 81(9), 30-36.

Yamak, H., Bulut, N. ve Dündar, S. (2014). 5. Sınıf Öğrencilerinin Bilimsel Süreç Becerileri ile Fene Karşı Tutumlarına FeTeMM Etkinliklerinin Etkisi. Gazi Üniversitesi Gazi Eğitim Fakültesi Dergisi, 34(2), 249-265.

Yaşar, S.., Baker, D., Robinson-Kurpius, S., Krause, S. ve Roberts, C. (2006). Development of a survey to assess K-12 teachers' perceptions of engineers and familiarity with teaching design, engineering, and technology. Journal of Engineering Education, 95(3), 205-215.

Zimmer, L. (2006). Qualitative meta-synthesis: a question of dialoguing with texts. Journal of Advanced Nursing, 53(3), 311-318. 


\section{Extended Abstract}

\section{Introduction}

STEM education aims to solve real life problems by using an interdisciplinary approach to mathematics, science, engineering and technology. Individuals raised in this direction are expected to contribute to the future economy with the 21 st century skills -critical and innovative thinking-. Ministry of National Education in Turkey has started integrating STEM education approach to curriculum because this approach is gaining importance globally. The number of studies related to STEM education in Turkey gradually increased in the last five years. In this study, studies related to STEM education in Turkey were synthesized with an aim to determine the common themes of the current situation. Therefore, the present study poses the following question: "Which common themes can be derived from the qualitative findings obtained from STEM education studies in Turkey?"

\section{Methodology}

In order to examine the STEM studies conducted in Turkey, a qualitative meta-synthesis was utilized. In this respect, literature review has been made with relevant keywords (e.g., "STEM", "STEM education", "STEM practices", "STEM teaching") in ERIC (Educational Resources Information Center), Web of Science, Scopus, Google Scholar, TUBITAK-ULAKBIM and Higher Education Council National Thesis Center. Studies on Biology and Medicine -including the concept of "STEM"- were removed and the studies that were carried out in the field of education were selected. Additionally, considering the purpose of the study, Turkey context is filtered. Initially, 58 studies were selected. Then, through the nature of the meta-synthesis studies, quantitative or mixed studies were excluded. Finally, 12 qualitative studies were included. The research process was conducted with the confirmation and consensus among the researchers and an additional expert who completed the doctoral education in the field of Curriculum and Instruction.

\section{Findings}

As a result of the initial analysis, three dimensions were obtained in STEM studies. The first dimension focused on the improvement of the skills in STEM fields in secondary and high school students and 21st century skills with the STEM practices done in or out of the school. The second dimension focused on the perceptions of students, pre-service teachers and teachers about STEM education, their awareness, and their opinions on STEM education after studies such as professional development programs and STEM practices. The majority of studies carried out in Turkey followed this trend to introduce STEM education as a new issue for Turkey. The third-dimension focused teachers' ability to establish interdisciplinary relationship in STEM disciplines.

In line with these dimensions, studies were reviewed and synthesized under three common themes. The first theme was 21st Century Skills and the STEM Interest. In this theme, it was stated that students were interested in STEM areas through STEM practices in or out of the school contexts. In addition, it was found that students gained interest in STEM areas with these practices and they developed 21st century skills. Also, in these practices, engineering processes and technology were found to be applied in school courses. This interdisciplinary interaction has positively influenced students' attitudes towards school subjects in STEM areas, 
and improved students' academic achievement, attitude, and problem-solving skills. However, these practices were merely limited to the science and technology courses. In other words, these practices were not used in the math or information technologies courses which are directly related to the STEM fields. Moreover, practices with pre-service teachers were generally limited to science and technology teachers. In these practices, it was seen that engineering processes were handled with simple machines, construction of bridge figures and/or robotic practices. During these practices, students had an active role. To do so, students were encouraged to be more systematic in problem solving and collaborative work. The integration of engineering design processes in school courses helped students to acquire 21 st century skills, such as producing innovative solutions, critical thinking, and conducting scientific research. Also, robotic practices were found to contribute to the engineering design and problem-solving processes by means of algorithm and mathematics and technology knowledge in coding process.

The second theme focused on the perceptions and opinions on STEM education. In this theme, the effects of STEM practices on teachers and pre-service teachers were investigated. In addition, the studies examined under this theme showed that teachers who specialize in only one STEM discipline gained new experiences through practices. As a result of the studies, it was concluded that teachers, pre-service teachers and students had positive perceptions on STEM education.

The third theme focused on teachers' and pre-service teachers' ability to establish interdisciplinary relationship along STEM disciplines. Teachers were trained to specialize in one of the STEM areas (such as science, chemistry, biology, physics, mathematics or IT), but an interdisciplinary approach is essential for effective STEM education. In the studies, it was analyzed that teachers had an active role in various workshops and in-service training programs and/ or professional development programs. At the same time, it was seen that using instructional practices like group work and brainstorming helped the participants to develop some 21 st century skills (such as communication, collaboration, critical thinking, and creativity).

\section{Conclusions}

This meta-synthesis study aimed to provide an insight to the potential studies in this fertile area. As a result of the findings, it was emphasized that the students from different classes, as future labor force, can develop their existing skills through STEM practices and direct their career interests to STEM areas. In addition, it was found that students who have negative attitudes towards STEM courses have changed their attitudes positively by means of STEM practices. Teachers and pre-service teachers expressed positive opinions about STEM education. It was observed that teachers and pre-service teachers realized the interdisciplinary nature of STEM education and they were willing to integrate engineering design processes into their courses. However, they complained about the potential problems about allocating adequate material and appropriate time.

STEM education is a recent popular research area in Turkey. However, it has long been debate in international literature. At this point, more qualified STEM education studies are recommended in Turkey. Rather than merely examining STEM education, there is a need to develop holistic studies that will involve all stakeholders of the education for the contextual analysis and enhancing the current knowledge of STEM education. The current studies were 
generally focused on the science course and for future work, it is recommended to carry out studies in areas such as mathematics and information technologies related to STEM fields. In doing so, it is expected to reach new approaches and conclusions that would help new debates and studies related to the curricula in these areas. This synthesis emphasizes that the 21st century skills will be acquired through different practices, and the disciplines within STEM will provide individuals with a different perspectives that individuals could reach higher level of cognitive skills. 